February 2022

\title{
Strategic event planning in hospitality: The need to recommit, post COVID
}

Nancy Hutson

Full Stop Productions Inc., nhutson@fullstoppro.com

Follow this and additional works at: https://digitalcommons.usf.edu/jght

Part of the Hospitality Administration and Management Commons, and the Strategic Management Policy Commons

This View Point is brought to you for free and open access by the M3 Center at the University of South Florida Sarasota-Manatee at Digital Commons @ University of South Florida. It has been accepted for inclusion in Journal of Global Hospitality and Tourism by an authorized editor of Digital Commons @ University of South Florida. For more information, please contact digitalcommons@usf.edu.

\section{Recommended Citation}

Hutson, N. (2022). Strategic event planning in hospitality: The need to recommit, post COVID. Journal of Global Hospitality and Tourism, 1(1), 88-89. https://www.doi.org/10.5038/2771-5957.1.1.1006

Corresponding Author

Nancy Hutson, 2161 6TH Ave. North, St. Petersburg, Florida, 33713 


\title{
Strategic Event Planning in Hospitality: The Need to Recommit, Post Covid
}

\author{
Nancy Hutson
}

Full Stop Productions Inc., Florida

nhutson@fullstoppro.com

Recharging the hospitality industry post-covid is a critical issue. While tourism and hospitality continue to show signs of rebounding, new, innovative strategies in event planning are needed more than ever (Ali et al., 2021). Hospitality and tourism organizations need to reshape the customer experience and find strategies to engage with customers as we go through financial resilience and experience a new norm of travel post-COVID-19 (Lee, 2021). By creating a compelling consumer event plan, theme parks, restaurants, and hotels can create their reasons for guests to visit multiple times throughout a year, increasing spend and brand affinity, both critical to business success. While all guests are valuable to the hotel industry, the positive economics of repeat customers can't be ignored. Building customer loyalty is one of the most important steps for a hotel's success (Avey, 2018).

First, we must understand and agree on who the guest currently is and who we want to encourage for further visits. Events can drive both repeat visitations for our current promoter and entice new demographics (Kaushal \& Srivastava, 2021). By having a full understanding of the current situation and the desired outcome, an event could be developed to increase volume and spending. For example, if the restaurant has a well-attended dining area and slow bar, they may choose to focus a series of events at the bar area where margins are high, and they currently have room for greater attendance. By creating a wine tasting, beer tasting shot special, and drink special of the month program, the energy and marketing of the bar events can put focus on a new customer in an area that has room for capacity.

Another piece of a strategic event plan would be to know the current market and what events might stimulate the attendance you are looking for. By doing additional research on the local area and competition, a hospitality leader could seek to identify gaps in the current event options. Also, connecting with suppliers to understand what might be working or new in other markets. Additionally, seeking partnerships for events can be a useful tool in understanding what might drive additional visitation and spending. Hotels can even partner and become preferred hotels for citywide or destination events and therefore get a piggyback effect from another event effort. A hotel could also offer missing pieces to an existing event to help connect business for example a ride to and from an event to avoid parking hassle and fees.

Finally, identifying when an event is needed to boost visitation and profitability. Would it make more sense to peek the peeks, so to speak, and add an event to an already busy time to capitalize on an existing holiday or busy season? Or perhaps, focusing on a shoulder season, or less attended period of time would make more sense to boost a slower period. Both strategies have validity and when combined with the additional planning of demographics and competitive market can lead to a clear direction for an effective event strategy. 
Committing to the developed strategy is key to long-term success. In my experience, once the plan is developed, a minimum of three years must be committed to fully understanding the success of any event strategy. This not only allows for the full cycle of the development of the event strategy but ensures a level of buy in from senior management to front line team members and appropriate funding for success. Year one is a great proof of concept and interest by delivering an excellent event and superior marketing, year two seeks to streamline processes and refine business goals with year three reaping the financial and brand affinity benefits of a successful event.

While research has been done regarding the amount of repeat visitation, more study would help understand the reasons why guests choose to visit a particular hospitality establishment multiple time (Solakis et al., 2022). Is great food enough of a reason to return to a restaurant or would the layering on of a specific week of wine tasting events be more compelling? How can a restaurant strategically pulse meaningful events for their customers throughout the year and create must attend reasons to visit again and again? Future industry leaders in the hospitality and tourism industry need to know how we can create authentic, unique, and memorable customer experiences to attract demand (Lee, 2021). The world's appetite for travel is growing stronger and stronger, this is a critical time to attract an early resurgence of booking demand (Baidin, 2021). By having a strategic event plan in place hospitality establishments can strive to regain, and potentially surpass, pre-Covid attendance and profits.

\section{References}

Ali, F., Dogan, S., Amin, M., Hussain, K., \& Ryu, K. (2021). Brand anthropomorphism, love, and defense: Does attitude towards social distancing matter? The Service Industries Journal, 41(1-2), 58-83.

Avey, C. (2018, December). Why repeat hotel customers are better than new ones? Hospitalitynet.com. https://www.hospitalitynet.org/opinion/4091173.html

Baidin, I. (2021, May 3). Three post-pandemic travel trends to watch this year. Forbes. https://www.forbes.com/sites/forbesbusinesscouncil/2021/05/03/three-post-pandemic-travel-trends-towatch-this-year/?sh=4a90c0c06a2e

Kaushal, V., \& Srivastava, S. (2021). Hospitality and tourism industry amid COVID-19 pandemic: Perspectives on challenges and learnings from India. International Journal of Hospitality Management, 92, 1-9.

Lee, S. J. (2021, July). Hospitality and tourism in a post-covid world. Institutional Repository for the Kent State University. https://www.kent.edu/ehhs/hospitality-and-tourism-post-covid-world.

Solakis, K., Peña-Vinces, J., \& Lopez-Bonilla, J. M. (2022). Value co-creation and perceived value: A customer perspective in the hospitality context. European Research on Management and Business Economics, 28(1), $1-10$. 